\title{
Zmožnost učencev v branju besed v začetku i. razreda
}

Marija Ropič Kop, Saša Klar Zadravec

\section{Uvod}

Branje je ena izmed štirih sporazumevalnih dejavnosti v osnovni šoli pri slovenščini in je deležno posebne pozornosti pri pouku $\mathrm{v} 1$. razredu. $\mathrm{V}$ teoretičnem uvodu bomo skušali nekoliko osvetliti vzrok, zakaj imajo učenci ob vstopu v 1. razred tako različno razvito zmožnost branja, da eni že berejo, drugi pa ne.

Zaradi lažjega razumevanja prisotnosti branja $\mathrm{v} 1$. razredu bomo najprej pogledali, kako je opredeljeno branje. Različne opredelitve branja kažejo na to, da je branje zelo kompleksno. Prva opredelitev (Pečjak, 1999) poudarja proces dekodiranja oz. prepoznavanja tiskanih ali pisanih simbolov (črk). Branje je percipiranje vrstnega reda črk in njihove sinteze. Pri tem bralec več časa posveti elementom besed, obliki in velikosti črk. Druga opredelitev (ibid.) poudarja proces razumevanja in označuje branje kot psiholingvistični proces, pri katerem bralci po svojih zmožnostih rekonstruirajo sporočila, ki so podana v pisni ali grafični obliki. Tretja opredelitev (ibid.) opredeljuje branje kot integracijo dekodiranja in razumevanja in predpostavlja, da je branje v prvi vrsti proces dekodiranja besed, ki je odvisen od povezave novih besed s pojmi iz bralčevega spomina. V naslednji fazi pa gre za proces razumevanja besedila. Četrta opredelitev (ibid.) predstavlja branje kot večstopenjski proces, $\mathrm{v}$ katerem sodelujejo različne sposobnosti. 
V našem teoretičnem razmišljanju, ki se močno povezuje z zmožnostjo branja konec predšolskega obdobja in začetka osnovne šole pred sistematičnim opismenjevanjem, smo pregledali faze usvajanja bralne tehnike različnih avtorjev (Gray, 1925; Chall, 1983; povz. iz Pečjak, 1999) in zasledili različna mnenja o pripravi na branje in začetnem branju, ki pa so še zmeraj aktualna. Grayeva (1925) prva stopnja, ki obsega predšolsko obdobje in začetek osnovne šole, vsebuje pripravo na branje. Avtor meni, da naj to obdobje razvija sposobnost pripovedovanja in govornega razumevanja ter spodbuja rast besedišča in interes za branje. Ta faza naj bi poskrbela za natančno in pravilno izgovorjavo ter razvila zmožnost vidnega in slušnega razločevanja. V naslednji fazi začetnega obdobja bralnega pouka naj učenci razvijajo interes za branje in sposobnost branja ter pomnjenja enostavnih besedil. Ob tem spodbujajo željo učencev po samostojnem in neodvisnem branju. Challova (1983) meni, da otroci predšolskega obdobja v predbralnem obdobju pridobivajo znanje o govorjenem in pisnem jeziku ter znanje o črkah, besedah in knjigah. Učenci nato vzpostavijo asociativno zvezo med glasom in črko ter razvijajo sposobnost vidnega in slušnega razločevanja. Avtorica je poudarila pomen zgodnjega in sistematičnega pouka glasovnega zavedanja. V omenjeni stopnji sledimo trem fazam bralnega razvoja, in sicer je $\mathrm{v}$ prvi fazi bralec bolj pozoren na pomen kot na obliko in $\mathrm{v}$ drugi fazi na grafično podobo. $V$ tretji fazi tekoče in natančno bere. Omenjenemu sledi stopnja utrjevanja spretnosti branja. $Z$ utrjevanjem bralne tehnike težimo $k$ avtomatizaciji branja. Hitrejše in natančno branje pa vodi $\mathrm{k}$ boljšemu razumevanju. Obe opredelitvi poudarjata pripravo na šolo, ki zajema osnove branja.

Podobno navajajo tudi drugi avtorji (Manyak, 2008; Strickland, 2011, Ropič Kop, 2020). Na dekodiranje v opismenjevanju vpliva proces vidnega zaznavanja, pri čemer gre za zaznavanje in prepoznavanje grafičnih simbolov, in proces slušnega zaznavanja. Na sposobnost dekodiranja pozitivno učinkuje zgodnje sistematično spodbujanje glasovnega zavedanja.

Ena od raziskav (Papadimitriou in Vlachos, 2014), ki preverja povezanost glasovnega zavedanja $\mathrm{z}$ učenjem branja in pisanja, je potrdila pozitivno povezavo med njimi. Posebne spretnosti, ki se razvijajo v predšolskem obdobju, napovedujejo bralno uspešnost, tudi natančnost in tekočnost branja v 1. in 2. razredu osnovne šole. Prepoznavanje otrok s primanjkljaji predbralnih zmožnosti v predšolskem obdobju in odpravljanje teh težav bi lahko zmanjšalo nastanek učnih težav pri branju. 
Nekatere študije (Chard in Dickson, 1999; Ropič, 2017; Zorman, 2005) izkazujejo težavnostne stopnje oz. ravni glasovnega zavedanja. Na uspešnost glasovnega zavedanja vpliva tudi dolžina besed (Levin, 2007). Pri zaznavanju začetnih in končnih glasov v besedah so izsledki raziskave (Ropič, 2016) opozorili na upravičenost razvrščanja v nezložne in večzložne besede ter na pomen ustreznega načrtovanja glasovnega zavedanja $\mathrm{v}$ predšolskem obdobju, ki mora potekati načrtno in natančno skozi daljše časovno obdobje. Potrebo po načrtnem in natančnem razvoju glasovnega zavedanja skozi daljši čas izražajo tudi druge študije (npr. Cadoso-Matinset et al., 2010; Castles et al., 2012; Mesmer in Griffith, 2005). Učenci imajo ob vstopu v 1. razred različno razvite zmožnosti zaznavanja začetnih in končnih glasov oz. obstajajo med učenci velike individualne razlike. Nekateri učenci še ne zaznavajo začetnih glasov v besedi, še več nezmožnosti pa opazimo pri zaznavanju končnih glasov. Od teh učencev ni mogoče pričakovati, da bodo kmalu zaznavali tudi glasove $\mathrm{v}$ besedah in njihovo zaporedje, saj gre za najzahtevnejšo raven (Ropič Kop, 2020). Glede vprašanja, ali spol vpliva na zmožnost glasovnega zavedanja, ki ima pomemben vpliv na uspešnost v branju, obstajajo različna mnenja. Študije (Bider Petelin, 2014; Ropič Kop, 2020) ne ugotovijo statistično značilnih razlik v zaznavanju začetnih in končnih glasov med dečki in deklicami.

Na zmožnost branja vpliva tudi pomoč učencem pri razrešitvi raznih težav pri branju. Študije (Balbi et al., 2020; Lathouras et al., 2019) opozarjajo na pridobivanje pomoči osnovne pismenosti pri branju v začetnih letih učencem s šibkim socialno-ekonomskim statusom in šibkim znanjem jezi$\mathrm{ka}, \mathrm{v}$ katerem se šolajo. Preverili so glasovno zavedanje, črkovanje, tekoče branje in razumevanje. Ugotovitve kažejo, da je pomoč pozitivno učinkovala. Študija (Ecalle et al., 2006) ugotavlja, da majhni razredi (10-12 učencev) vplivajo na dve osnovni spretnosti, in sicer na branje (prepoznavanje besed) in na črkovanje (naštevanje besed), niso pa prinesli učnih koristi učencem s šibkim socialno-ekonomskim statusom in učencem, katerih prvi jezik ni francoščina.

Cilj empirične raziskave je bil preveriti predznanje učencev na področju branja na začetku 1. razreda 1. razreda pred sistematičnim opismenjevanjem. Za pridobitev čim bolj realnega stanja na tem področju smo izbrali velikost vzorca (192 učencev), ki smo ga zmogli individualno preveriti. Z osnovnimi šolami sodelujemo $\mathrm{v}$ različnih dejavnostih, zato so nas učiteljice seznanile $\mathrm{z}$ osnovnimi informacijami, kot na primer, da nekatere osnovne šole všolajo bistveno več učencev priseljencev in da več učencev prihaja iz 
manj spodbudnega okolja oz. iz družin s šibkim socialnoekonomskim statusom. Oblikovali smo dve skupini. V skupini A je bilo več učencev iz manj spodbudnega okolja s pomanjkljivim znanjem oz. brez znanja slovenskega jezika in večjim tveganjem pri sistematičnem opismenjevanju. V skupini B učencev priseljencev ni bilo oz. je bil v posameznem oddelku le eden in so večinoma prihajali iz bolj spodbudnega okolja.

Branje besed smo razporedili po težavnostni stopnji v štiri skupine, s čimer smo se približali bralni zmožnosti učencev.

Izvedena raziskava bo v prvi vrsti v neprecenljivo pomoč učiteljem pri oblikovanju diferenciacije in individualizacije v oddelkih. Prav tako bo raziskava informirala o stanju branja učencev ob vstopu v osnovno šolo.

\section{Metodologija}

Individualno smo preverili 192 učencev 1 . razreda, ki smo jih razdelili v dve skupini. V skupini A je bilo 98 učencev in v skupini B 94 učencev. Učenci A in B skupine so se med seboj bistveno razlikovali, in sicer je bilo v skupini A več učencev iz družin priseljencev in s šibkim socialno-ekonomskim statusom. Za preverjanje branja smo skrbno pripravili šestnajst besed, ki smo jih po težavnostni stopnji razvrstili v štiri sklope. V kolikor učenci niso prebrali iz prvega sklopa nobene besede, niso nadaljevali z branjem drugega sklopa ipd. Za vsako prebrano besedo so dobili eno točko, to pomeni pridobitev maksimalno štirih točk v enem sklopu. Skupno so lahko v branju šestnajstih besed dosegli šestnajst točk.

$\mathrm{Na}$ nivoju branja, ki zajema dekodiranje oz. vezavo dveh črk/glasov v besedi, smo izbrali štiri besede (sklop branja besed 1). V tem sklopu je zgradba treh besed podobna (soglasnik-samoglasnik), četrta beseda je zveza samoglasnika in soglasnika. Naslednji sklop štirih besed (sklop branja besed 2) je bil nekoliko zahtevnejši, saj je vseboval po tri črke. V treh primerih je bila zgradba podobna (soglasnik-samoglasnik-soglasnik) in v enem primeru nekoliko težja (samoglasnik-soglasnik-samoglasnik). Tretja skupina besed je imela štiri besede in vsaka je imela štiri črke (sklop branja besed 3). Zgradba teh je bila podobna (soglasnik-samoglasnik-soglasnik-samoglasnik). V četrto skupino štirih besed (sklop branja besed 4) smo izbrali najtežje besede, ki so bile sestavljene iz petih do sedmih črk. Njihova zgradba je bila težja tudi zato, ker je vsebovala soglasniške sklope.

Za proučevanje razlik med skupinama učencev 1 . razreda v branju besed in besedila smo uporabili deskriptivno in kavzalno-neeksperimentalno metodo empiričnega raziskovanja. Za analizo značilnosti razlik med sku- 
pinama smo v skupnem številu vseh prebranih besed in v skupnem številu prebranih besed posameznega sklopa uporabili t-preizkus za neodvisne vzorce. Ker nas je zanimalo, kakšne razlike se kažejo med učenci obeh skupin, ali je prisotna povezanost in kakšne so frekvence v zmožnosti branja na nivoju posamezne besede $v$ posameznem sklopu, smo uporabili $\chi^{2}$-test. Pridobljene podatke smo obdelali s programom SPSS. Rezultate smo prikazali v tabelah in jih interpretirali.

\section{Rezultati raziskave in razprava}

Tabela 3 predstavlja statistično značilno razliko ( $\mathrm{p}=0,000)$ med skupinama A in B v prid skupini B. Učenci skupine B so uspešnejši kot učenci skupine A v branju štirih najlažjih besed. V skupini B so prebrali 2,o1 od štirih besed, v skupini A le 1,o9 besed. Učencem je branje olajšalo zaznavanje začetnih črk (glasov), ki se pretežno pojavijo kot soglasniki. Vse besede so imele le po dve črki. Osnovni proces, ki se zgodi pri branju teh besed, je spajanje dveh črk/glasov v besedo.

Standardni odklon odraža zelo velike individualne razlike med učenci obeh skupin. Prav tako kaže, da tudi v skupini B določeni učenci nimajo predznanja na področju branja, čeprav je ta delež učencev bistveno manjši kot v skupini A.

Tabela 3: Rezultati t-testa za neodvisne vzorce učencev skupin A in B v branju »sklopa besed $\mathrm{I} \ll$

\begin{tabular}{cccccc} 
Skupina & $n$ & $M$ & $S D$ & $F(p)$ & $t(p)$ \\
A & 98 & 1,09 & 1,493 & & \\
B & 94 & 2,01 & 1,793 & $16,444(0,000)$ & $-3,850(0,000)$ \\
\hline
\end{tabular}

Tabela 4 predstavlja statistično značilno razliko $\mathrm{v}$ rezultatih branja učencev skupin A in B. 60,2 \% učencev skupine A še ne bere v začetku 1. razreda. Slabih štirideset odstotkov učencev je prebralo od ene do štiri besede iz »sklopa besed $1 \ll$.

Iz tabele je razvidno, da 40,4 \% učencev skupine B v začetku 1. razreda ne bere. $34 \%$ učencev te skupine prebere vse štiri besede in $17 \%$ učencev prebere tri od štirih besed. Trije učenci skupine B preberejo eno besedo in pet učencev dve besedi, kar skupno predstavlja 8,5 \% učencev skupine B.

Med učenci skupin A in B je pomembna razlika v deležu učencev, ki še ne berejo. Prav tako je velika razlika med učenci skupin A in B v deležu 
vseh prebranih besed »sklopa besed 1«, in sicer v skupini A prebere vse štiri besede 10,2 \% učencev in v skupini B 34 \% učencev.

Rezultati branja najlažjih besed t-testa za neodvisni vzorec pokažejo statistično značilno razliko med skupinama $A$ in $B(p=0,000)$. $Z$ rezultati $\chi^{2}$-testa smo zagotovili podrobnejši vpogled v rezultate. Ti pokažejo, da v skupini A 60,2 \% učencev ne bere in da vse štiri besede prebere le 10,2 \% učencev, medtem ko v skupini B ne bere 40,4 \% učencev in vse štiri besede prebere kar 34,0 \%. Skratka, v obeh skupinah je velika razlika v številu učencev, ki berejo in tistih, ki ne berejo. Ob tem ugotavljamo velike individualne razlike v branju učencev v obeh skupinah.

V skupnem deležu branja iz »sklopa besed 1 « učencev skupin A in B sta zanimiva podatka, da 50,5\% vseh preverjanih učencev ne bere besed in da 21,9 \% učencev prebere vse štiri besede.

Pri branju smo zabeležili nekaj napak, ki pa so v branju pomenile novo smiselno besedo in, zato do samokorekcije branja ni prišlo. To nas opozarja na potrebo spremembe instumentarija pri ponovni izvedbi branja besed $(n i-i n, o b-b o)$.

Tabela 4: Rezultati - testa učencev skupin A in B v številu prebranih besed $\gg$ sklopa besed I $\ll$

\begin{tabular}{ccccccc}
\hline \multirow{2}{*}{$\begin{array}{c}\text { Število } \\
\text { besed }\end{array}$} & \multicolumn{2}{c}{ Skupina A } & \multicolumn{2}{c}{ Skupina B } & \multicolumn{2}{c}{ Skupaj } \\
\cline { 2 - 7 } & $\mathrm{f}$ & $\mathrm{f} \%$ & $\mathrm{f}$ & $\mathrm{f} \%$ & $\mathrm{f}$ & $\mathrm{f} \%$ \\
\hline $\mathrm{o}$ & 59 & 60,2 & 38 & 40,4 & 97 & 50,5 \\
\hline 1 & 6 & 6,1 & 3 & 3,2 & 9 & 4,7 \\
\hline 2 & 8 & 8,2 & 5 & 5,3 & 13 & 6,8 \\
\hline 3 & 15 & 15,3 & 16 & 17,0 & 31 & 16,1 \\
\hline 4 & 10 & 10,2 & 32 & 34,0 & 42 & 21,9 \\
\hline Skupaj & 98 & 100 & 94 & 100 & 192 & 100 \\
\hline$\chi^{2}=17,719$ & $\mathrm{p}=0,001$ & & & & & \\
\hline
\end{tabular}

Rezultati tabele 3 v glasnem branju vseh štirih besed (ni, ta, če, ob) kažejo statistično značilno razliko med skupinama A in B. V skupini B je bilo značilno več učencev, ki so v začetku 1. razreda že znali brati. Branje prvih treh besed se začne na soglasnik ( $n, t, \check{c})$, ki mu je dodan $v$ besedah različen samoglasnik (i, a, e). Največjo razliko v branju omenjenih treh besed ugotavljamo v besedi »ta «, kjer je 55,3 \% učencev skupine B pravilno prebralo besedo. Nekoliko manjšo razliko beležimo v besedi »če«. Sledi razlika med skupinama A in B v branju besede »ob«, ki se začne na samoglasnik in mu sledi soglasnik. 
Te izsledke lahko povežemo $s$ tem, da otroci najprej zaznajo besede, ki se pričnejo s soglasnikom (Leven, 2007). Najmanjša razlika v branju na nivoju »sklopa besed 1 " med učenci skupin A in B je v branju besede »ni«. Zaznali smo težavo, saj je nekaj učencev napravilo zamenjavo črk/glasov in prebralo »in«. Domnevamo, da se niso popravili v branju, saj se jim je zdela beseda smiselna. Prav tako smo v redkih primerih zaznali podobno napako pri branju besede »ob«. Prebrali so »bo«. Branje besed »ni« in »ob«prav tako razkriva natančnost branja učencev.

Tabela s: Rezultati - testa skupin A in B v zmožnosti branja »sklopa besed I «

\begin{tabular}{|c|c|c|c|c|c|c|c|c|c|c|c|c|c|}
\hline \multirow[t]{3}{*}{ Besede } & \multicolumn{4}{|c|}{ Skupina A } & \multicolumn{4}{|c|}{ Skupina B } & \multicolumn{4}{|c|}{ Skupaj } & \multirow[t]{2}{*}{$\begin{array}{c}\text { Rezultati } \\
\chi^{2} \text { - testa }\end{array}$} \\
\hline & \multicolumn{2}{|c|}{ o } & \multicolumn{2}{|c|}{1} & \multicolumn{2}{|c|}{0} & \multicolumn{2}{|c|}{1} & \multirow{2}{*}{$\begin{array}{l}\mathrm{o} \\
\mathrm{f}\end{array}$} & \multirow{2}{*}{$\begin{array}{c}1 \\
\mathrm{f} \%\end{array}$} & \multirow[t]{2}{*}{0} & \multirow[t]{2}{*}{1} & \\
\hline & $\mathrm{f}$ & $\mathrm{f} \%$ & $\mathrm{f}$ & $\mathrm{f} \%$ & $\mathrm{f}$ & f $\%$ & $\mathrm{f}$ & $\mathrm{f} \%$ & & & & & $\chi^{2}$ \\
\hline ni & 69 & 70,4 & 29 & 29,6 & 51 & 54,3 & 43 & 45,7 & 120 & 62,5 & 72 & 37,5 & $\begin{array}{l}\chi^{2}=5,341 \\
p=0,021\end{array}$ \\
\hline ta & 69 & 70,4 & 29 & 29,6 & 42 & 44,7 & 52 & 55,3 & 111 & 57,8 & 81 & 42,2 & $\begin{aligned} \chi^{2} & =13,021 \\
p & =0,000\end{aligned}$ \\
\hline če & 74 & 75,5 & 24 & 24,5 & 48 & 51,1 & 46 & 48,9 & 122 & 63,5 & 70 & 36,5 & $\begin{array}{l}\chi^{2}=12,377 \\
p=0,000\end{array}$ \\
\hline $\mathrm{ob}$ & 68 & 69,4 & 30 & 30,6 & 46 & 48,9 & 48 & 51,1 & 114 & 59,4 & 78 & 40,6 & $\begin{array}{l}\chi^{2}=8,320 \\
p=0,004\end{array}$ \\
\hline
\end{tabular}

V branju nekoliko zahtevnejše skupine besed »sklopa besed 2 « v primerjavi z branjem »sklopa besed 1 " so bili uspešnejši učenci skupine $B$, saj se je med skupinama potrdila statistično značilna razlika $(\mathrm{p}=0,001)$.

Tabela 6 prikazuje rezultate branja sklopa besed, ki je bilo nekoliko zahtevnejše. Zgradba je tipična; $v$ njej štejejo besede po tri črke, $v$ treh od štirih primerih se beseda začne in konča na soglasnik in v enem primeru se začne in konča na samoglasnik.

Aritmetična sredina kaže, da so učenci skupine B prebrali 1,88 od štirih besed. $V$ kolikor primerjamo to povprečje $\mathrm{z}$ doseženim povprečjem najlažjih besed (tabela 4) opazimo za o,13 slabši rezultat. Z branjem zahtevnejših besed se rezultati v skupini B postopoma slabšajo. Učenci v skupini A so v povprečju prebrali 1,09 besed, kar predstavlja enak rezultat v povprečju prebranih besed na nivoju branja najlažjih besed.

V skupini B se je delež učencev, ki so prebrali vse besede tega sklopa, nekoliko zmanjšal. Razlika v branju tega sklopa ostaja statistično značilna $(\mathrm{p}=\mathrm{o}, \mathrm{oo1})$ med skupinama, kjer so uspešnejši učenci skupine B. 
Iz rezultatov standardnega odklona razberemo velike individualne razlike med učenci obeh skupin, še zlasti skupine B.

Tabela 6: Rezultati t-testa za neodvisne vzorce učencev skupin A in B v branju »sklopa besed $2 \ll$

$\begin{array}{cccccc}\text { Skupina } & n & M & S D & F(p) & t(p) \\ \text { A } & 98 & 1,09 & 1,560 & & \\ \text { B } & 94 & 1,88 & 1,777 & 10,180(0,002) & -3,273(0,001)\end{array}$

Tabela 7 predstavlja rezultate branja »sklopa besed $2 \lll$, kjer obstaja statistično značilna razlika med učenci skupin $\mathrm{A}$ in $\mathrm{B}(\mathrm{p}=0,012)$. Delež učencev v branju »sklopa besed 2 « se poveča za tri učence v obeh skupinah (A in B). V naboru besed branja se pojavijo zahtevnejše besede (luč, sir, ona, Jan).

Tabela 7: Rezultati - testa učencev skupin A in B v številu prebranih besed »sklopa besed $2 \ll$

\begin{tabular}{ccccccc} 
Število & \multicolumn{2}{c}{ Skupina A } & \multicolumn{2}{c}{ Skupina B } & \multicolumn{2}{c}{ Skupaj } \\
\cline { 2 - 6 } besed & $\mathrm{f}$ & $\mathrm{f} \%$ & $\mathrm{f}$ & $\mathrm{f} \%$ & $\mathrm{f}$ & $\mathrm{f} \%$ \\
\hline $\mathrm{o}$ & 62 & 63,3 & 41 & 43,6 & 103 & 53,6 \\
\hline 1 & 5 & 5,1 & 2 & 2,1 & 7 & 3,6 \\
\hline 2 & 3 & 3,1 & 6 & 6,4 & 9 & 4,7 \\
\hline 3 & 16 & 16,3 & 17 & 18,1 & 33 & 17,2 \\
\hline 4 & 12 & 12,2 & 28 & 29,8 & 40 & 20,8 \\
\hline Skupaj & 98 & 100 & 94 & 100 & 192 & 100 \\
\hline$\chi^{2}=12,920$ & $\mathrm{p}=0,012$ & & & & & \\
\hline
\end{tabular}

63,3 \% učencev skupine A ni prebralo nobene od štirih besed. 12 učencev te skupine je prebralo vse štiri besede. Rezultati izkazujejo velike individualne razlike $\mathrm{v}$ zmožnosti branja.

Razlike v branju so prisotne tudi med učenci v skupini B, čeprav je delež učencev, ki še ne berejo, 43,6 \%; delež učencev, ki preberejo vse štiri besede, predstavlja 29,8\% in delež učencev, ki preberejo tri besede, predstavlja $18,1 \%$. Število učencev, ki preberejo vse štiri besede ali tri od štirih besed, je 45 in presega število učencev, ki še ne berejo (41 učencev).

Zanimiv rezultat na ravni vseh učencev skupin A in B je, da 53,6 \% učencev še ne bere »sklopa besed 2 « in da $20,8 \%$ učencev pravilno prebere vse štiri besede.

S povečevanjem težavnostne stopnje branja v naslednjih sklopih se poveča število učencev $\mathrm{v}$ obeh skupinah v kriteriju ne berejo in v skupini A se rahlo poveča število učencev, ki so prebrali vse štiri besede. Delež učencev, 
ki še ne berejo, se v tem sklopu v primerjavi z branjem »sklopa besed 1" poveča. Nekoliko se zmanjša delež učencev, ki preberejo vse štiri besede.

Rezultati glasnega branja nekoliko zahtevnejših besed v tabeli 8 kažejo na statistično značilno razliko $\mathrm{v}$ predznanju na področju branja med skupinama A in B. Skoraj polovica učencev skupine B je uspešnih v branju že na začetku 1. razreda in njihova uspešnost se giblje med 43,6 \% in 48,9\%. Ti učenci že samostojno berejo preproste besede.

Največjo razliko $\mathrm{v}$ uspešnosti branja med skupinama A in B opazimo v branju besede »luč«. V skupini B to besedo ustrezno prebere skoraj polovica otrok, v skupini A pa le dobra četrtina.

Tri od štirih besed imajo preprosto zgradbo: soglasnik-samoglasnik-soglasnik in ena od štirih besed ima nekoliko zahtevnejšo zgradbo: samoglasnik-soglasnik-samoglasnik. Rezultate $\mathrm{v}$ branju lahko deloma primerjamo z uspešnostjo zaznave soglasnikov in samoglasnikov $\mathrm{v}$ začetku besed $\mathrm{z}$ drugo sorodno raziskavo (Leven, 2007). Največjo statistično značilno razliko v branju besed izkazujejo besede, ki imajo na začetku soglasnik, in najmanjšo razliko branje besed, ki se začnejo na samoglasnik.

Tabela 8: Rezultati - testa skupin A in B v zmožnosti branja »sklopa besed $2 \ll$

\begin{tabular}{|c|c|c|c|c|c|c|c|c|c|c|c|c|c|}
\hline \multirow[t]{3}{*}{ Besede } & \multicolumn{4}{|c|}{ Skupina A } & \multicolumn{4}{|c|}{ Skupina B } & \multicolumn{4}{|c|}{ Skupaj } & \multirow[t]{2}{*}{$\begin{array}{c}\text { Rezultati } \\
\chi^{2} \text { - testa }\end{array}$} \\
\hline & & 0 & & 1 & & o & & 1 & 0 & 1 & 0 & 1 & \\
\hline & $\mathrm{f}$ & $\mathrm{f} \%$ & $\mathrm{f}$ & $\mathrm{f} \%$ & $\mathrm{f}$ & $f \%$ & $\mathrm{f}$ & $\mathrm{f} \%$ & $\mathrm{f}$ & $\mathrm{f} \%$ & & & $x^{2}$ \\
\hline luč & 73 & 74,5 & 25 & 25,5 & 48 & 51,1 & 46 & 48,9 & 121 & 63,0 & 71 & 37,0 & $\begin{array}{l}\chi^{2}=11,298 \\
p=0,001\end{array}$ \\
\hline $\operatorname{sir}$ & 73 & 74,5 & 25 & 25,5 & 53 & 564 & 41 & 43,6 & 126 & 65,6 & 66 & 34,4 & $\begin{array}{l}\chi^{2}=6,973 \\
p=0,008\end{array}$ \\
\hline ona & 69 & 70,4 & 29 & 29,6 & 49 & 52,1 & 45 & 47,9 & 118 & 61,5 & 74 & 38,5 & $\begin{array}{l}\chi^{2}=6,769 \\
p=0,009\end{array}$ \\
\hline Jan & 70 & 71,4 & 28 & 28,6 & 49 & 52,1 & 45 & 47,9 & 119 & 62,0 & 73 & 38,0 & $\begin{array}{l}\chi^{2}=7,585 \\
p=0,006\end{array}$ \\
\hline
\end{tabular}

Rezultati tabele 9 kažejo na statistično značilno razliko $(\mathrm{p}=0,000)$ med učenci skupin A in B v branju tretjega sklopa, ki predstavlja že sklop branja precej težkih besed oz. »sklopa besed 3 «. Povprečje prebranih besed v skupini $B$ je 1,71 besed od štirih. Ti učenci so bili manj uspešni v povprečju za o,17 prebranih besed $\mathrm{v}$ primerjavi $\mathrm{z}$ branjem besed prejšnje oz. nekoliko manj zahtevne skupine besed (sklop besed 2). Učenci skupine A so prebrali v povprečju le o,86 besed od štirih. Tudi v tej skupini opazimo postopno slabšo uspešnost $\mathrm{v}$ povprečju za 0,23 besed $\mathrm{v}$ primerjavi $\mathrm{z}$ branjem 
besed prejšnje zahtevnostne skupine. Skratka, učenci obeh skupin so postopoma manj uspešni v branju besed.

Standardni odklon v obeh skupinah opozarja na velike individualne razlike med učenci, ki so še izrazitejše med učenci skupine $B$.

\section{Tabela 9: Rezultati t-testa za neodvisne vzorce učencev skupin A in B v branju »sklopa besed $3 \ll$}

\begin{tabular}{cccccc} 
Skupina & $n$ & $M$ & $S D$ & $F(p)$ & $t(p)$ \\
A & 98 & 0,86 & 1,499 & & \\
B & 94 & 1,71 & 1,788 & $17,607(0,000)$ & $-3,586(0,000)$ \\
\hline
\end{tabular}

Iz tabele 10 je razvidna statistično značilna razlika $(\mathrm{p}=0,007)$ med učenci skupin A in B v zmožnosti branja »sklopa besed 3". Delež učencev v skupini A, ki ne zmorejo prebrati nobene predložene besede, se poveča za devet. Skupno je teh učencev v skupini A 72,4 \%. Prav tako se delež učencev v skupini B, ki ne preberejo nobene besede v »sklopu besed 3", poveča za tri učence, kar skupno predstavlja 46,8 \%.

Tabela ıo: Rezultati - testa učencev skupin A in B v številu prebranih besed »sklopa besed $3 \ll$

\begin{tabular}{ccccccc} 
Število & \multicolumn{2}{c}{ Skupina A } & \multicolumn{2}{c}{ Skupina B } & \multicolumn{2}{c}{ Skupaj } \\
\cline { 2 - 6 } besed & $\mathrm{f}$ & $\mathrm{f} \%$ & $\mathrm{f}$ & $\mathrm{f} \%$ & $\mathrm{f}$ & $\mathrm{f} \%$ \\
\hline 0 & 71 & 72,4 & 44 & 46,8 & 115 & 59,9 \\
\hline 1 & 3 & 3,1 & 5 & 5,3 & 8 & 4,2 \\
\hline 2 & 4 & 4,1 & 8 & 8,5 & 12 & 6,3 \\
\hline 3 & 7 & 7,1 & 8 & 8,5 & 15 & 7,8 \\
\hline 4 & 13 & 13,3 & 29 & 30,9 & 42 & 21,9 \\
\hline Skupaj & 98 & 100 & 94 & 100 & 192 & 100 \\
\hline$\chi^{2}=14,257$ & $\mathrm{p}=0,007$ & & & & & \\
\hline
\end{tabular}

Prav tako zabeležimo večje spremembe v obeh skupinah učencev v deležu treh od štirih prebranih besed, ki se zmanjša v skupini A na sedem učencev in v skupini B na osem učencev. Poveča se delež vseh prebranih besed tega sklopa, in sicer $v$ obeh skupinah za enega učenca.

Skupni delež učencev skupin A in B se poveča v nezmožnosti branja tega sklopa na 59,9 \% vseh preverjenih učencev. Rahlo se poveča tudi skupno število učencev, ki so prebrali vse štiri besede. V uspešnosti branja vseh štirih besed oz. »sklopa besed 3" je ta delež popolnoma enak kot v branju »sklopa besed 1« (21,9\%). 
$\mathrm{V}$ tem sklopu ne moremo prezreti tega, da se delež učencev v skupini A, ki ne berejo, vidno poveča že na dobrih $72 \%$. Nekateri učenci v skupini A so uspeli prebrati le lažje besede prejšnjega sklopa. To opraviči nujnost razporeditve besed v težavnostne skupine. Delež učencev v skupini B, ki ne berejo, se počasi veča. V branju nekoliko zahtevnejšega sklopa besed se odraža vpliv (ne)spodbudnega okolja in potrjuje ugotovitve drugih raziskav (Ecalle et al., 2006; Lathouras et al., 2019).

Rezultati tabele 11 izkazujejo v branju »sklopa besed 3"statistično značilno razliko med skupinama A in B. Rezultati tega sklopa besed kažejo na največjo razliko $(\mathrm{p}=0,000) \mathrm{v}$ branju besede $»$ muca . Skoraj polovica učencev skupine B je prebrala besedo »muca«, v skupini A je bilo v branju te besede uspešnih le 20,4 \% učencev. Nekoliko manjša razlika je v branju besede »sova«. Še manjšo razliko ugotavljamo v branju besed »šola« in »repa«. Enako število učencev iz skupine B je uspešnejših pri branju besed »šola" in »repa« in enako število učencev iz skupine A je prebralo besedi »šola« in »repa«.

Vse besede iz tega sklopa imajo podobno zgradbo: soglasnik-samoglasnik-soglasnik-samoglasnik. Ta zgradba nudi oporo v branju tistim bralcem, ki najprej tiho oz. glasno črkujejo in nato glasno povežejo glasove črk v paru. To pogosto pomeni na primer naslednje: učenec poimenuje glasove črk besede »muca: $\mathrm{m}-\mathrm{u}-\mathrm{c}-\mathrm{a} \ll$. Nato poveže »mu-ca«. Nekateri učenci nato tudi ponovijo prebrano besedo bolj povezano (»muca«).

$\mathrm{V}$ primerjavi rezultatov te tabele s prejšnjimi opazimo, da se uspešnost branja zmanjšuje s težavnostno stopnjo oz. z zahtevnostjo zgradbe besed. Prav tako opazimo, da beležimo v branju zadnjih dveh besed (»šola«, »repa «) na nivoju vseh učencev skupin A in B le 30,2 \% uspešnost.

Tabela ır: Rezultati - testa skupin A in B v zmožnosti branja »sklopa besed $3 \ll$

\begin{tabular}{|c|c|c|c|c|c|c|c|c|c|c|c|c|c|}
\hline \multirow[t]{3}{*}{ Besede } & \multicolumn{4}{|c|}{ Skupina A } & \multicolumn{4}{|c|}{ Skupina B } & \multicolumn{4}{|c|}{ Skupaj } & \multirow[t]{2}{*}{$\begin{array}{c}\text { Rezultati } \\
\chi^{2}-\text { testa }\end{array}$} \\
\hline & \multicolumn{2}{|c|}{0} & \multicolumn{2}{|c|}{1} & \multicolumn{2}{|c|}{0} & \multicolumn{2}{|c|}{1} & \multirow{2}{*}{$\begin{array}{l}\mathrm{o} \\
\mathrm{f}\end{array}$} & \multirow{2}{*}{$\begin{array}{c}1 \\
\mathrm{f} \%\end{array}$} & \multirow[t]{2}{*}{0} & \multirow[t]{2}{*}{1} & \\
\hline & $\mathrm{f}$ & f \% & $\mathrm{f}$ & $f \%$ & f & $f \%$ & $\mathrm{f}$ & $f \%$ & & & & & $x^{2}$ \\
\hline muca & 78 & 79,6 & 20 & 20,4 & 48 & 51,1 & 46 & 48,9 & 126 & 65,6 & 66 & 34,4 & $\begin{array}{l}\chi^{2}=17,309 \\
p=0,000\end{array}$ \\
\hline sova & 76 & 77,6 & 22 & 22,4 & 53 & 56,4 & 41 & 43,6 & 129 & 67,2 & 63 & 32,8 & $\begin{array}{l}\chi^{2}=9,752 \\
\mathrm{p}=0,002\end{array}$ \\
\hline šola & 77 & 78,6 & 21 & 21,4 & 57 & 60,6 & 37 & 39,4 & 134 & 69,8 & 58 & 30,2 & $\begin{array}{l}\chi^{2}=7,319 \\
\mathrm{p}=0,007\end{array}$ \\
\hline repa & 77 & 78,6 & 21 & 21,4 & 57 & 60,6 & 37 & 39,4 & 134 & 69,8 & 58 & 30,2 & $\begin{array}{l}\chi^{2}=7,319 \\
p=0,007\end{array}$ \\
\hline
\end{tabular}


V tabeli 12 zasledimo statistično značilno razliko $(\mathrm{p}=0,007) \mathrm{v}$ branju najtežjih besed oz. v branju »sklopa besed 4" med skupinama A in B. Učenci skupine B so prebrali v povprečju 1,39 besed od štirih, medtem ko učenci skupine A v povprečju le 0,77 besed.

Branje besed $v$ tem sklopu je najzahtevnejše, saj vsebuje pet do sedem črk, od tega imata dve besedi po en soglasniški sklop in ena beseda dva soglasniška sklopa.

Učenci skupine B so kljub temu, da so uspešnejši v branju besed v primerjavi $\mathrm{z}$ učenci skupine A v povprečnem branju besed glede na težavnostno stopnjo, $v$ tem nivoju branja manj uspešni v povprečju za o,32 besed. Njihovi vrstniki v skupini A so dosegli v povprečju prebranih besed le za 0,09 besed slabši rezultat.

Standardni odklon na nivoju branja najtežjih besed obstaja velik v obeh skupinah. To pomeni, da so $v$ branju besed med učenci v obeh skupinah velike individualne razlike.

Tabela I2: Rezultati t-testa za neodvisne vzorce učencev skupin A in B v branju »sklopa besed $4 \ll$

\begin{tabular}{cccccc} 
Skupina & $n$ & $M$ & $S D$ & $F(p)$ & $t(p)$ \\
\hline A & 98 & 0,77 & 1,434 & & $18,629(0,000)$ \\
B & 94 & 1,39 & 1,743 & & $-2,721(0,007)$ \\
\hline
\end{tabular}

Rezultati tabele 13 kažejo, da razlike med učenci skupin A in B niso statistično značilne. Delež učencev v skupini A, ki ne preberejo nobene besede, se poveča na $73,5 \%$. Delež učencev v skupini B, ki ne preberejo nobene besede, se poveča kar za osem učencev in predstavlja $55,3 \%$ učencev. Ob tem je zanimivo, da vse besede prebere le 12,2 \% učencev skupine A in 24,5 $\%$ učencev skupine $\mathrm{B}$.

Rezultati kažejo, da se $\mathrm{z}$ večanjem težavnostne stopnje branja $\mathrm{v}$ posameznem sklopu besed povečuje nezmožnost branja pri učencih obeh skupin. Prav tako se nekoliko zmanjša število učencev $\mathrm{v}$ obeh skupinah, ki zmorejo prebrati vse besede »sklopa besed 4«.

V skupini A beležimo približno enako število učencev v branju vseh štirih sklopov besed, in sicer $\mathrm{v} »$ sklopu besed 1 « deset učencev, $\mathrm{v} » s k l o p u$ besed 2 « dvanajst učencev, v»sklopu besed 3 « trinajst učencev in v »sklopu besed 4" dvanajst učencev. Če strnemo razmišljanje o tem, lahko rečemo, da učenci, ki berejo, berejo več ali manj vse besede v vseh štirih sklopih branja. 
V skupini B opazimo, da se delež v zmožnostih branja posameznih sklopov besed precej spreminja. Dvaintrideset učencev skupine B je prebralo vse besede »sklopa besed 1«, v »sklopu besed 2 « je bilo uspešnih osemindvajset učencev, $\mathrm{v}$ »sklopu besed 3 " devetindvajset učencev in $\mathrm{v}$ »sklopu besed 4« triindvajset učencev.

\begin{tabular}{|c|c|c|c|c|c|c|}
\hline \multirow{2}{*}{$\begin{array}{c}\text { Število } \\
\text { besed }\end{array}$} & \multicolumn{2}{|c|}{ Skupina A } & \multicolumn{2}{|c|}{ Skupina B } & \multicolumn{2}{|c|}{ Skupaj } \\
\hline & f & $\mathrm{f} \%$ & f & $\mathrm{f} \%$ & f & $f \%$ \\
\hline o & 72 & 73,5 & 52 & 55,3 & 124 & 64,6 \\
\hline 1 & 7 & 7,1 & 8 & 8,5 & 15 & 7,8 \\
\hline 2 & 1 & 1,0 & 2 & 2,1 & 3 & 1,6 \\
\hline 3 & 6 & 6,1 & 9 & 9,6 & 15 & 7,8 \\
\hline 4 & 12 & 12,2 & 23 & 24,5 & 35 & 18,2 \\
\hline Skupaj & 98 & 100 & 94 & 100 & 192 & 100 \\
\hline$\chi^{2}=7,603$ & $p=o$, & & & & & \\
\hline
\end{tabular}

Rezultati tabele 14 opozarjajo na statistično značilno razliko v branju besed »sklopa besed 4 « v prvih treh besedah, ne pa tudi v branju najzahtevnejše besede v tem sklopu, besede »krompir«.

Največja razlika med skupinama $(\mathrm{p}=0,002)$ se odraža v branju besede »sliva«. V skupini B je prebralo to besedo 35,1 \% učencev, medtem ko v skupini A le 15,3\%. V zgradbi besede je soglasniški sklop oz. zaporedje dveh soglasnikov v začetku besede, kar pričakovano oteži branje. Prav tako je pomemben podatek, da enako število učencev B skupine prebere besedi «jesen« in »sliva«. V skupini A prebere besedo »sliva« pet učencev manj kot besedo »jesen«. V začetnem branju je pomembna zgradba besed (npr. soglasnik-samoglasnik-soglasnik-samoglasnik-soglasnik).

Branje besede s soglasniškim sklopom se nahaja tudi v besedi »torba«, a je znotraj besede. Učenci obeh skupin so bili v branju te besede uspešnejši in razlika med njimi je bila $\mathrm{v}$ uspešnosti branja te besede nekoliko manjša $(\mathrm{p}=0,007)$.

Prav tako beležimo manjše razlike med učenci skupin A in B v branju prve besede »sklopa besed 4« (»jesen«), ki je po obsegu črk zahtevnejša od besed »sklopa besed 3«, čeprav ne vsebuje soglasniškega sklopa v besedi.

Rezultat branja besede »krompir« ne izkazuje statistično značilne razlike med skupinama. Obstaja pa tendenca $(\mathrm{p}=0,067)$, ki opozarja na večjo uspešnost $\mathrm{v}$ branju te besede učencev skupine $\mathrm{B}$, saj je to besedo prebralo 
30,9 \% učencev, v skupini A pa le 19,4 \% učencev. Beseda »krompir« je sestavljena iz sedmih črk. Zahtevnost branja besede povečata dva soglasniška sklopa, in sicer »kr« na začetku besede in "mp« znotraj besede. Iz rezultatov te tabele razberemo še zanimivost, da le $25 \%$ vseh učencev skupin A in B prebere besedi »sliva« in »krompir«.

Prav tako se v branju najzahtevnejšega sklopa besed odraža vpliv (ne) spodbudnega okolja. Rezultati naše raziskave potrjujejo ugotovitve drugih raziskav (Ecalle et al., 2006; Lathouras et al., 2019).

Tabela I4: Rezultati - testa skupin A in B v zmožnosti branja »sklopa besed $4 \ll$

\begin{tabular}{|c|c|c|c|c|c|c|c|c|c|c|c|c|c|}
\hline \multirow[t]{3}{*}{ Besede } & \multicolumn{4}{|c|}{ Skupina A } & \multicolumn{4}{|c|}{ Skupina B } & \multicolumn{4}{|c|}{ Skupaj } & \multirow[t]{2}{*}{$\begin{array}{c}\text { Rezultati } \\
\chi^{2} \text { - testa }\end{array}$} \\
\hline & \multicolumn{2}{|c|}{0} & \multicolumn{2}{|c|}{1} & \multicolumn{2}{|c|}{0} & \multicolumn{2}{|c|}{1} & \multirow{2}{*}{$\begin{array}{l}\mathrm{o} \\
\mathrm{f}\end{array}$} & \multirow{2}{*}{$\frac{1}{\mathrm{f} \%}$} & \multirow[t]{2}{*}{0} & \multirow[t]{2}{*}{1} & \\
\hline & $\mathrm{f}$ & $\mathrm{f} \%$ & $\mathrm{f}$ & $\mathrm{f} \%$ & $\mathrm{f}$ & $\mathrm{f} \%$ & $\mathrm{f}$ & $\mathrm{f} \%$ & & & & & $x^{2}$ \\
\hline jesen & 78 & 79,6 & 20 & 20,4 & 61 & 64,9 & 33 & 35,1 & 139 & 72,4 & 53 & 27,6 & $\begin{array}{l}\chi^{2}=5,187 \\
p=0,023\end{array}$ \\
\hline slive & 83 & 84,7 & 15 & 15,3 & 61 & 64,9 & 33 & 35,1 & 144 & 75,0 & 48 & 25,0 & $\begin{array}{c}\chi^{2}=10,032 \\
p=0,002\end{array}$ \\
\hline torba & 77 & 78,6 & 21 & 21,4 & 57 & 60,6 & 37 & 39,4 & 134 & 69,8 & 58 & 30,2 & $\begin{array}{l}\chi^{2}=7,319 \\
p=0,007\end{array}$ \\
\hline krompir & 79 & 80,6 & 19 & 19,4 & 65 & 69,1 & 29 & 30,9 & 144 & 75,0 & 48 & 25,0 & $\begin{array}{l}\chi^{2}=3,363 \\
p=0,067\end{array}$ \\
\hline
\end{tabular}

\section{Zaključek}

Raziskava je pokazala pomembno razliko v branju med učenci skupin A in B. V skupini B srečamo več učencev, ki berejo že ob vstopu v 1. razred. To pomeni, da so se učenci naučili brati že pred všolanjem. Znano je, da če so predšolski otroci v vrtcu in okolju deležni ustreznega spodbujanja na govornem področju ter vidnega in slušnega zaznavanja in pridobijo določeno znanje o pisnem jeziku (črke, besede, knjige), pogosto spontano vstopijo $\mathrm{v}$ svet branja (Pečjak, 1999; Ropič Kop, 2020).

Raziskava je izčrpno odgovorila na naša vprašanja. Med učenci osnovnih šol na območju nizkega socialno-ekonomskega statusa je pomembno več učencev z manjšim predznanjem. Rezultati raziskave opozorijo na pomembne stvari v praksi. Predšolsko obdobje mora načrtno skrbeti za uspešen govorni razvoj otrok, razvijati vidno in slušno zaznavanje ter nuditi otrokom pestre izkušnje v svetu črk in knjig za razvijanje bralnega interesa. Prav tako je pomembno zgodnje odkrivanje učencev, ki potrebujejo pomoč pri učenju branja. Ko so težave manjše, jih lažje odpravimo oziroma omilimo. 
Poznavanje predznanja učencev je za učitelje 1. razreda nujno, saj mora pridobivanje črk, branje in pisanje potekati ob upoštevanju diferenciacije in individualizacije.

Pred ponovnim preverjanjem predznanja učencev v branju bomo nekoliko spremenili seznam besed drugega sklopa. Poskrbeli bomo za izbor štirih besed, kjer bosta dve z začetnim samoglasnikom in dve z začetnim soglasnikom. V času obdelave podatkov smo se soočili z vprašanjem, ali bi bili rezultati v omenjenem sklopu drugačni, če bi bile besede uravnotežene tudi glede na začetno črko besede. To smatramo za pomanjkljivost raziskave.

Ob zaključeni raziskavi se poraja že novo vprašanje, in sicer, kako uspešno bo sistematično opismenjevanje učencev obeh skupin in ali se bodo razlike $\mathrm{v}$ branju zmanjšale ali povečale do konca 1 . razreda. Pomembno vprašanje je, ali predznanje s področja branja $z$ začetka 1. razreda osnovne šole pomembno vpliva na uspešnost branja (hitrost branja, ritem branja, izraznost branja, pravilnost branja, razumevanje $\mathrm{z}$ nižje in višje ravni razumevanja branja) ob koncu 1 . VIO in kakšne so korelacije med posameznimi kriteriji branja v 3. razredu. Prav to želimo preučiti v naslednji študiji.

\section{Literatura}

Balbi, Alejandra, von Hagen, Alexa, Jimenez, Juan E. and Cuadro, Ariel. „Efficacy of an Evidence-Based Literacy Intervention for Spanish Speaking Struggling Readers from Vulnerable Socio- Economic Status.“ Electronic Journal of Research in Educational Psychology 18 no. 50 (2020): 201-222. Accessed December 1, 2020. http://ojs.ual.es/ojs/index.php/EJREP/article/ view/2692/3459

Bara, Florence, Gentaz, Edouard and Cole, Pascale. „Haptics in Learning to Read with Children from Low Socio-Economic Status Families.“ British jounal of Developmental Psychology 25, no. 4 (2007): 643-663.

Bider Petelin, Ivanka. „Ugotavljanje predbralnih zmožnosti.“ Sodobna pedagogika 65 no. 131 (2014): 24-40. Accessed November 10, 2020. http://dx.doi. org.ezproxy.lib.ukm.si/10.1348/026151007X186643

Chall, Jeanne. S. Stages Of Reading Development. New York: McGraw-Hill Book Company, 1983.

Cardoso-Martins, Claudia, Mesquita, Tereza Cristina Lara and Ehri, Linnea. „Letter names and phonological awareness help children to learn letter-sound relations." Journal of Experimental Child Psychology 109 no. 1 (2010): 25-38. 
Castles, Anne, Coltheart, Max, Wilson, Katherine, Valpied, Jodie and Wedgwood, Joanne. „The genesis of reading ability: What helps children learn letter-sound correspondences?" Journal of Experimental Child Psychology 104 no. 1 (2009): 68-88.

Ecalle, Jean, Magnan, Annie and Gibert, Fabienne. „Class Size Effects on Literacy Skills and Literacy Interest in First Grade: A Large-Scale Investigation." Journal of School Psychology 44 no. 3 (2006): 191-209. Accessed November 16, 2020. http://dx.doi.org.ezproxy.lib.ukm.si/10.1016/j. jsp.2006.03.002

Gray, William. S. 1925. 24th Yearbook of the NSSE. Part 1 - Report of the National Committee on Reading. Bloomington: Publing School Publishing Co.

Haramija, Dragica. (Eds.). Bralna pismenost v predšolski vzgoji in izobraževanju. Maribor: Pedagoška fakulteta v Mariboru, 2017.

Lathouras, Maria, Westerveld, Marleen and Trembath, David. „Longitudinal Reading Outcomes in Response to a Book-Based, Whole Class Intervention for Students from Diverse Cultural, Linguistic and Socio-Economic Backgrounds." Australian Journal of Learning Difficulties 24 no. 2 (2019), 147-161. Accessed November 12, 2020. http://dx.doi.org.ezproxy.lib.ukm.si/ 10.1080/19404158.2019.1640755

Manyak, Patrick C. „Phonemes in Use: Multiple Activities for a critical Process." The Reading Teacher 61 no. 8 (2008): 659-662.

Mesmer, Heidi Anne E. and Griffith Pricilla L. „Everybody's selling It-But Just What is Explicit, Systematic phonics Instruction?" The Reading Teacher 59 no. 4 (2005): 366-376.

Pečjak, Sonja. Osnove psihologije branja. Ljubljana: ZIFF, 1999.

Pečjak, Vid . Hitro in uspešno branje. Ljubljana: Samozaložba, 1991.

Ropič, Marija. „Zmožnost zaznavanja začetnih in končnih glasov v nezložnih in večzložnih besedah. "Didactika Slovenica - Pedagoška obzorja 31 no. 1 (2016): 44-55.

Ropič, Marija. „Razvoj določenih ravni glasovnega zavedanja v predšolskem obdobju." V:

Ropič Kop, Marija. The Ability to Perceive Initial and Final Sounds in a Word. V: Lipovec, Alenka, Batič, Janja, Kranjec, Eva (ur.). New Horizons in Subject-Specific Education: Research Aspects of Subject-Specific Didactics. 2020, str. 53-69. https://press.um.si/index.php/ump/catalog/book/481.

Strickland, Dorothy S. „Strategies for Beginning Readers and Writers and Those Needing Additional Support and Intervention in Teaching phonics Today." Newark, DE: International Reading Association, (2011): 50-56. 